\title{
Variations in reproductive and egg traits correlation estimates of two strains of Archachatina marginata snails (var. ovum and var. saturalis) and crosses
}

"Ibom, L. A., Okon, B., Dauda, A. and Patani, I

Department of Animal Science, University of Calabar, Calabar, Nigeria

"Corresponding author: ibomlawrence@gmail.com, Tel: +2348033508663

\section{Abstract}

$\overline{\text { A study was conducted to assess variations in the reproductive traits and egg traits }}$ correlation estimates of the two strains of Archachatina marginata snails (var. ovum and var. saturalis) and their crosses. Ninety sexually mature A. marginata snails, forty-five each of the two strains (var. saturalis and var. ovum) were selected from a base population for the study. The live weight of the snails ranged from $256.43-566.25 \mathrm{~g}$ for both strains. Selection of the snails was based on active appearance and lack of injury on the foot and on shells. The snails were randomly allotted into three mating models (treatments) of 30 each of var. saturalis, var. ovum and mixed strains (at 15 var. ovum : 15 var. saturalis). The models were designated as homozygous var. ovum main cross (AMO XAMO), homozygous var. saturalis main cross (AMS XAMS) and heterozygous (var. ovum $x$ var. saturalis) cross (AMOXAMS). Each of the three models was replicated 15 times with two snails to a tub/cell for purposes of reproduction. Results from the study showed that the three mating models expressed significant $(P<0.05)$ differences in the reproductive traits evaluated. Whereas some of the traits were not significantly $(P>0.05)$ different between the AMO XAMO and AMOXAMS mating models, significant $(P<0.05)$ differences existed between all the traits when the AMS $X A M S$ mating model was compared with the AMOXAMO and AMOXAMS mating models.

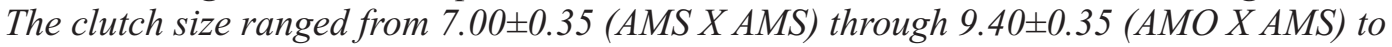
$9.90 \pm 0.35$ (AMO X AMO), while the values for mean egg weight at lay ranged from $1.59 \pm 0.03 \mathrm{~g}$ (AMS X AMS) through $1.78 \pm 0.03 \mathrm{~g}$ (AMO X AMO) to $1.79 \pm 0.03 \mathrm{~g}$ (AMOX AMS). Percent hatchability value was highest in the AMO X AMO mating model $(93.30 \%)$, followed by the AMS X AMS mating model (91.10\%), while the AMO XAMS mating model recorded the lowest value ( $88.50 \%)$. Percent survivability value was highest in the AMOX AMS mating model (84.00\%), followed by the AMO X AMO mating model (82.00\%), while the AMS X AMS mating model recorded the lowest value (80.00\%). The egg traits correlation estimates $\left(r_{p}\right)$ revealed that except for one pair of trait each in the mating models, all the other pairs of traits expressed positive and significant correlation coefficients/values. The AMOX AMS mating model recorded the highest correlation $\left(r_{p}\right)$ value (0.826) for the pair of ELH vs $E W H$, while the AMS X AMS mating model recorded the lowest correlation $\left(r_{p}\right)$ value (0.058) for the pair of ELH vs CSE. The percent egg shell colour distribution showed that the shell of eggs laid by the homozygous crosses (AMOX XMO and AMS XAMS) expressed two colours. The egg shell of eggs laid by AMO X AMO mating model expressed mikado yellow and maize yellow colours, while those laid by AMS X AMS mating model expressed mikado yellow and amber colours. The shell of eggs laid by the heterozygous cross however expressed three colours; mikado yellow, maize yellow and amber. Based on the reproductive traits results, it could be recommended that the AMO X AMS mating model be adopted by farmers for optimum production and returns on investment.

Keywords: Correlation, reproduction, snails, strains, traits, variations

Introduction

Due to the prevailing economic recession in Nigeria, the farming of giant African land snails, achatiniculture has become a new frontier to generate income and improve the livelihood of people as well as curb 


\section{Variations in reproductive and egg traits}

unemployment. This is perhaps because snail farm can be started with little capital and the management practices are easy (Omole et al., 2011). Besides, Ademosun and Imevbore (1988) reported that snail meat (Congo meat) compares favourably with other protein sources in terms of protein, amino acids and vitamin contents. Nigeria is richly endowed with land snail breeds (Archachatina marginata, Achatina achatina, Achatina fulica and Limicolaria species) and their production on large scale could be a succor and relief to the dwindling economic earnings of individuals and the nation. However, these snail breeds vary in size, colour, adaptability and performance (Amusan and Omidiji, 1998; Okon et al., 2012a). Besides, the reproductive ability of snails as well as other farm animals is to a large extent influenced by genetic (strain/genotype, age of the breeder, physiology, mating ratio, semen quality and dose, possession of major genes) and nongenetic/environmental (nutrition, exposure to light, water, medication) factors.

According to Amubode (1994); Okon et al. (2012a), Archachatina marginata and Achatina achatina are the two most abundantly distributed and popular breeds of land snail in Nigeria. On the other hand, Omole (1997) reported that A. marginata is the most common edible land snail found and reared in Nigeria. These snails play important role in the economy of rural families where they serve as the cheapest sources of animal protein, especially during the rainy season (period of abundance) (Ibom et al., 2011). The A. marginata snail breed has two varieties/strains ( $A$. marginata var. ovum and $A$. marginata var. saturalis) which are similar in various characteristics (foot colour, meat quality, habitat, shell shape and pattern, etc). The difference between these varieties/strains is in the colour of the columella (outer lip) and parietal wall of their shells. The colour of the columella and parietal wall of the shell of A. marginata var. ovum is bluish-white or white, while the columella and parietal wall of the shell of A. marginata var. saturalis is somewhat reddish or apricot red. This difference could be genetic in origin and have effects on the snail's traits, including reproductive traits.

Earlier reports on the reproductive performance of Archachatina marginata snails combined these two varieties/strains (var. ovum and var. satuiralis) as one breed and this has not really given out the true difference(s) in the performance of these varieties/strains. This study examined variations in the reproductive traits and egg traits correlation estimates of the two strains of $A$. marginata snails (var. ovum and var. saturalis) and their crosses.

\section{Materials and methods Experimental site}

This research was conducted at the Botanical Garden, University of Calabar, Calabar, Nigeria. Calabar is geographically situated between latitude $4^{\circ} 58^{\prime}$ and $15^{\circ} 39^{\prime} \mathrm{N}$ and longitude $8^{\circ} 17^{\prime}$ and $10^{\circ} 43^{\prime} \mathrm{E}$ of the equator, with annual temperature and rainfall ranges of $25^{\circ} \mathrm{C}$ to $28^{\circ} \mathrm{C}$ and $1260 \mathrm{~mm}$ to $1280 \mathrm{~mm}$ respectively. The relative humidity rarely drops below $60 \%$ and fluctuates between 90 and $100 \%$ most months of the year (NMA, 2016). The area where this study was conducted possessed a mini-climate similar to the natural habitat of snails. The area has some permanent tree crops (mango, gmelina, almond and pawpaw), cultivated crops (cassava and yam) and undergrowth of wild shrubs. These plants provided shade that protected the hutches and snails from harsh environmental factors such as heavy rainfall, direct sunlight and high ambient temperature. 


\section{Experimental animals}

Ninety sexually mature Archachatina marginata snails, 45 each of the two strains/varieties (var. saturalis and var. ovum) were selected from a base population purchased from a reputable snail farm in Calabar, Nigeria. The live weight of the snails ranged from $256.43-566.25 \mathrm{~g}$ for both strains/varieties. Selection of the snails was based on active appearance and lack of injury on the foot and on shells. The snails: var. saturalis $(\mathrm{n}=45)$ and var. ovum $(n=45)$ were randomly allotted into three mating models (treatments) of $30 \mathrm{var}$. saturalis, 30 var. ovum and 30 mixed varieties (15 var. ovum : 15 var. saturalis).
The models were designated as homozygous var. ovum main cross (AMO $\mathrm{X}$ AMO), homozygous var. saturalis main cross (AMS X AMS) and heterozygous (var. ovum $\mathrm{x}$ var. saturalis) cross (AMO X AMS). The snails were balanced weight for weight to ensure uniformity in average weight for all three models (treatments). Each of the three models was replicated fifteen (15) times with two snails to a tub/cell for purposes of reproduction. Confining two snails in a tub ensured that eggs collected from there are the product of mating between these two. The mating arrangement is shown in Table 1.

Table 1: Mating arrangement of experimental animals

\begin{tabular}{lcc}
\hline \multicolumn{1}{c}{ Mating model } & $\begin{array}{c}\text { Number of } \\
\text { snails }\end{array}$ & $\begin{array}{c}\text { Number of } \\
\text { cells/tubs }\end{array}$ \\
\hline Homozygous var. ovum main cross (AMO X AMO) & 2 & 15 \\
Homozygous var. saturalis main cross (AMS X AMS) & 2 & 15 \\
Heterozygous (var. ovum x var. saturalis) cross (AMO X AMS) & 2 & 15 \\
\hline
\end{tabular}

$\mathrm{AMO}=A$. marginata var. ovum, $\mathrm{AMS}=A$. marginata var. saturalis

\section{Management of experimental snails}

The experimental snails were housed in a hutch compartment raised $30 \mathrm{~cm}$ from the ground and contained series of tubs measuring $40 \mathrm{~cm}$ (length) $\times 40 \mathrm{~cm}$ (width) $\mathrm{x}$ $30 \mathrm{~cm}$ (depth). The bottom of the tubs were perforated (to allow drainage of excess moisture) and lined with sterilized loamy soil. The snails were reared on a mixed feeding regime of pawpaw leaves and concentrate. The concentrate was formulated to contain $25 \% \mathrm{CP}, 12 \% \mathrm{Ca}$ and $2650 \mathrm{Kcal} / \mathrm{kgME}$ using the following ingredients; maize offal $33 \%$, soybean meal $36 \%$, wheat offal $12 \%$, PKC $6 \%$, crayfish dust $8 \%$, bone meal $4.50 \%$ and mineral $/$ vitamin premix $0.50 \%$. Feed and water were given ad libitum throughout the experimental period (35 weeks).

\section{Management of eggs}

Eggs collected from the three mating models of the snails were sorted against cracks and other physical deformities before measurements (egg weight, egg length and egg width) were taken. Thereafter, good eggs were incubated in improvised incubators (plastic containers perforated at the bottom and lined with sterilized loamy soil). The soil was sterilized to eliminate pathogenic organisms that would have otherwise attacked and killed the eggs. Incubated eggs were monitored until hatch.

\section{Data collection}

Data were collected on reproductive traits: clutch size (counted as the number of eggs laid by each mating model), egg weight at lay, egg length at lay, egg width at lay, hatchling weight at hatch, hatchling shell length at hatch, hatchling shell width at hatch, percent hatchability and percent survivability] of the snails. The eggs quality in terms of colour was determined by matching the colour of eggs shell against a 


\section{Variations in reproductive and egg traits}

standard colour chart (Raggett, 2002). Weights were measured using S. Miller ${ }^{\circledR}$ electronic scale with sensitivity of $0.01 \mathrm{~g}$, while the dimensional shell traits were measured using Vernier caliper.

\section{Statistical analysis}

Reproductive traits data were subjected to analysis of variance (ANOVA) using Genstat (2014), while significant means among traits were separated using Duncan's Multiple Range Test (Duncan, 1955). Correlation estimates of egg traits were done according to methods outlined by
Falconer (1989) and Ibe (1998). Percent hatchability and percent survivability were estimated according to the procedures of $\operatorname{Ibom}(2009)$.

\section{Results and discussion}

The results of reproductive traits of the three mating models [homozygous var. ovum main cross (AMO X AMO), homozygous var. saturalis main cross (AMS X AMS) and heterozygous (var. ovum $\mathrm{x}$ var. saturalis) cross (AMO X AMS)] are shown in Table 2.

Table 2: Reproductive performance of Archachatina marginata snails mating models

\begin{tabular}{|c|c|c|c|c|}
\hline Parameter & AMO X AMO & AMS X AMS & AMO X AMS & SEM \\
\hline Mean clutch size & $9.90^{\mathrm{a}}$ & $7.00^{c}$ & $9.40^{\mathrm{b}}$ & 0.35 \\
\hline Mean egg weight at lay (g) & $1.78^{\mathrm{a}}$ & $1.59^{\mathrm{b}}$ & $1.79^{\mathrm{a}}$ & 0.03 \\
\hline Mean egg length at lay (mm) & $1.58^{\mathrm{b}}$ & $1.59^{\mathrm{b}}$ & $1.67^{\mathrm{a}}$ & 0.02 \\
\hline Mean egg width at lay (mm) & $1.26^{\mathrm{b}}$ & $1.23^{\mathrm{c}}$ & $1.30^{\mathrm{a}}$ & 0.01 \\
\hline Mean hatchling weight at hatch $(\mathrm{g})$ & $1.40^{\mathrm{a}}$ & $1.26^{\mathrm{c}}$ & $1.30^{\mathrm{b}}$ & 0.03 \\
\hline Mean hatchling shell length at hatch (mm) & $1.57^{\mathrm{a}}$ & $1.53^{\mathrm{b}}$ & $1.56^{\mathrm{a}}$ & 0.01 \\
\hline Mean hatchling shell width at hatch (mm) & $1.24^{\mathrm{a}}$ & $1.21^{\mathrm{b}}$ & $1.23^{\mathrm{a}}$ & 0.01 \\
\hline$\%$ Hatchability & $93.30^{\mathrm{a}}$ & $91.10^{\mathrm{b}}$ & $88.50^{c}$ & 1.39 \\
\hline$\%$ Survivability & $82.00^{\mathrm{b}}$ & $80.00^{c}$ & $84.00^{\mathrm{a}}$ & 1.16 \\
\hline
\end{tabular}

Significant $(\mathrm{P}<0.05)$ differences existed between the traits of the three mating models, with the heterozygous cross (AMO $\mathrm{X}$ AMS $)$ expressing superiority $(\mathrm{P}<0.05)$ in three traits (egg length at lay, egg width at lay and percent survivability) over the homozygous crosses (AMO X AMO and AMS X AMS). One of the homozygous cross (AMO X AMO) was however superior $(\mathrm{P}<0.05)$ in three traits (clutch size, hatchling weight at hatch and percent hatchability) to the heterozygous cross (BO $\mathrm{X}$ BS) and the other homozygous cross (AMS XAMS) (Table 2).

The clutch size results (Table 2) were higher than the range of 1 to 4 and 2 to 6 reported by Ubua (2004) for A. marginata var. ovum and $A$. marginata var. saturalis homozygous crosses respectively. These results were also higher than the range of 5.08 to 6.58 reported by Ibom et al. (2015) for $A$. marginata var. ovum snails. However, the results were within the range of 2 to 15 and 1 to 16 reported by Akintomide (2004) and Okon and Ibom (2012) respectively for $A$. marginata snails. The clutch size was also within the range of 2 to 13 and 1 to 9 reported by Ibom (2009) for black skinned and white skinned A. marginata snails, respectively.

The mean egg weight at lay showed that the AMO X AMO and AMO X AMS mating models were statistically the same $(\mathrm{P}>0.05)$, but superior $(\mathrm{P}<0.05)$ to the AMS XAMS mating model (Table 2). The results (range of $1.59 \mathrm{~g}$ to $1.79 \mathrm{~g}$ ) were within the range of $1.15 \mathrm{~g}$ to $1.83 \mathrm{~g}$ reported by Okon et al. (2012b) for $F_{I}$ Achatina achatina 


\section{Ibom, Okon, Dauda and Patani}

snails, but lower than the range of $2.6 \mathrm{~g}$ to $5.0 \mathrm{~g}$ reported by Amubode (1994) for A. marginata snails. These egg weights were lower than the values of $1.90 \mathrm{~g}$ and $1.80 \mathrm{~g}$ reported by Okon et al. (2009) and Ibom et al. (2008) as weight at lay for black skinned ectotype of A. marginata snails, respectively. The mean egg weight values were higher than the mean value at lay $(1.05 \mathrm{~g})$ reported in Ibom et al. (2008) for albino A. marginata snails. The mean egg length at lay showed that the heterozygous cross (AMO X AMS) was superior $(\mathrm{P}<0.05)$ to the homozygous crosses (AMO X AMO and AMS X AMS) which were statistically the same $(\mathrm{P}>0.05)$ (Table $2)$. The mean egg length values were close to the mean value $(1.61 \mathrm{~mm})$ reported by Ibom et al. (2008) for black skinned $A$. marginata snails, but higher than the mean value $(1.43 \mathrm{~mm})$ reported for albino ectotype of the same snail breed. The mean egg length values were lower than the mean values of $14.32 \mathrm{~mm}$ and $15.35 \mathrm{~mm}$ reported by Okon et al. (2010) for parities 1 and 2 respectively of albino $A$. marginata snails. The mean egg length was also lower than the values of $19.70 \mathrm{~mm}$ reported by Amubode (1994) for black skinned ectotype of A. marginata snails and 1.68 $\mathrm{mm}$ reported by Okon et al. (2012b) for $\mathrm{F}_{I}$ A. achatina snails. Similarly, the egg length were lower than the range values at lay $(1.22$ to $1.50 \mathrm{~cm})$ reported by Ibom et al. (2015) for A. marginata var. ovum snails. The results of mean egg width at lay (Table 2) expressed significant $(\mathrm{P}<0.05)$ differences across the mating models, with the AMO X AMS recording the highest value $(1.30 \mathrm{~mm})$, followed by the AMO X AMO (1.26 mm), while the AMS X AMS had the lowest value $(1.23 \mathrm{~mm})$. The mean egg width were close to the mean value of $1.29 \mathrm{~mm}$ reported by Ibom et al. (2008) for black skinned $A$. marginata snails, but higher than the mean value of $1.05 \mathrm{~mm}$ reported by the same authors for albino ectotype of the same snail breed. The mean egg width values were lower than the mean values of $10.78 \mathrm{~mm}$ and $10.94 \mathrm{~mm}$ reported by Okon et al. (2010) for parities 1 and 2 respectively of albino A. marginata snails. The mean egg width values were also lower than the range values at lay ( 0.97 to 1.23 $\mathrm{cm})$ reported by Ibom et al. (2015) for $A$. marginata var. ovum snails.

The results of mean hatchling weight at hatch of this study (Table 2) showed that significant differences $(\mathrm{P}<0.05)$ existed across the mating models. The AMO $\mathrm{X}$ AMO model recorded the highest value $(1.40 \mathrm{~g})$, followed by the AMO X AMS model $(1.30 \mathrm{~g})$, while the AMS X AMS model recorded the lowest value (1.26 g). The mean hatchling weight results were within the range of 0.69 to $1.42 \mathrm{~g}$ reported by Odido (2007), but lower than the range of 2.1 to $2.5 \mathrm{~g}$ reported by Akinnusi (2004) for black-skinned snails. The results were however higher than the range value of 0.53 to $0.93 \mathrm{~g}$ reported by Ibom et al. (2015) for A. marginata var. ovum snails. The results of mean hatchling shell length and width at hatch (Table 2) followed the same trend. The results showed that the AMO X AMS and AMO X AMO mating models were statistically the same $(\mathrm{P}>0.05)$, while they differed significantly $(\mathrm{P}<0.05)$ from the AMS X AMS mating model. The mean hatchling shell length at hatch were within the range values of $1.40 \mathrm{~mm}$ to $1.49 \mathrm{~mm}$ and $1.25 \mathrm{~mm}$ to $1.41 \mathrm{~mm}$ reported by Okon et al. (2012a) and Ibom et al. (2012) for black skinned A. marginata snails respectively. On the other hand, the mean hatchling shell width were higher than the range values of $1.00 \mathrm{~mm}$ to $1.18 \mathrm{~mm}$ reported by Okon et al. (2012b) for $F_{1} A$. achatina snails and 0.99 $\mathrm{mm}$ to $1.16 \mathrm{~mm}$ reported by Ibom et al. (2012) for black skinned A. marginata 
snails.

The percent hatchability results (Table 2) showed that significant $(\mathrm{P}<0.05)$ differences existed across the mating models. The AMO XAMO model recorded the highest value $(93.30 \%)$, followed by the AMS X AMS model $(91.10 \%)$, while the AMO X AMS model recorded the lowest value $(88.50 \%)$. The percent hatchability results were within the range of 77 to $100 \%$ and 0 to $100 \%$ reported by Wosu (2003) and Odido (2007) respectively for black-skinned snails. The percent hatchability was higher than the range of 50.50 to $58.58 \%$ reported by Ibom et al. (2015) for A. marginata var. ovum snails. The percent survivability results (Table 2) showed significant $(\mathrm{P}<0.05)$ differences across the mating models. The AMO X AMS model recorded the highest value $(84.00 \%)$, followed by the AMO X AMO model (82.00\%), while the AMS X AMS model recorded the lowest value $(80.00 \%)$. These values were lower than the value of $100 \%$ and range of 83.00 to $92.08 \%$ reported by Fapohunda et al. (2007) and Ibom et al. (2015), respectively. The results of egg traits correlation estimates $\left(r_{p}\right)$ of the homozygous crosses/models (AMS X AMS and AMO X
AMO) in this study are presented in Table 3. The results revealed that except for one pair of trait each in these mating models (AMS X AMS and AMO X AMO), all other pairs of traits evaluated expressed positive and significant correlation coefficients/values. The results further showed that the AMO X AMO mating model recorded higher correlation $\left(r_{p}\right)$ values than the AMS XAMS mating model for any given pair of traits (Table 3). This could imply that these traits were influenced by the same gene(s) in the same direction. Besides, selection and improvement of one of the positively correlated traits could lead to improvement in the other trait. The correlation $\left(r_{p}\right)$ coefficients corresponding to egg length (ELH) vs egg width (EWH) and egg length (ELH) vs clutch size (CSE) were the highest and the lowest respectively in both the AMO X AMO and AMS X AMS mating models. The results of egg traits correlation estimates $\left(r_{p}\right)$ of the heterozygous cross/model (AMO X AMS) are presented in Table 4. The results showed the same trend as those of the homozygous models (AMO X AMO and AMS X AMS); positive and significant correlation coefficients, except for one pair of the traits.

Table 3: Correlation ( $\left.r_{p}\right)$ estimates of egg traits of the homozygous mating models (AMS $\quad X$ AMS and AMO X AMO) of A. marginata snails

\begin{tabular}{lcccc}
\hline \multicolumn{5}{c}{ AMS X AMS } \\
\hline Trait & EWT & ELH & EWH & CSE \\
\hline EWT & 1.000 & $0.526^{* *}$ & $0.600^{* *}$ & $0.291^{*}$ \\
ELH & $0.536^{* *}$ & 1.000 & $0.784^{* *}$ & -0.058 \\
EWH & $0.604^{* *}$ & $0.820^{* *}$ & 1.000 & $0.202^{*}$ \\
CSE & $0.298^{*}$ & -0.060 & $0.208^{*}$ & 1.000 \\
Trait & EWT & ELH & EWH & CSE \\
& & AMO X AMO & &
\end{tabular}

EWT = Egg Weight, ELH = Egg Length, EWH = Egg Width, CSE = Clutch Size

$* *$ Significant $(\mathbf{P}<0.01), *=$ Significant $(\mathbf{P}<\mathbf{0 . 0 5})$ 
Ibom, Okon, Dauda and Patani

Table 4: Correlation $\left(\mathrm{r}_{\mathrm{p}}\right)$ estimates of egg traits of the heterozygous mating model (AMO X AMS) of $A$. marginata snails

\begin{tabular}{lcccc}
\hline \multicolumn{5}{c}{ AMO X AMS } \\
\hline Trait & EWT & ELH & EWH & CSE \\
\hline EWT & 1.000 & & & \\
ELH & $0.546^{* *}$ & 1.000 & & \\
EWH & $0.608^{* *}$ & $0.826^{* *}$ & 1.000 & 1.000 \\
CSE & $0.305^{*}$ & -0.062 & $0.214^{*}$ & \\
\hline
\end{tabular}

EWT $=$ Egg Weight, ELH $=$ Egg Length, EWH $=$ Egg Width, CSE $=$ Clutch Size

$* *=$ Significant $(\mathbf{P}<0.01), *=$ Significant $(\mathbf{P}<0.05)$

The positive correlation $\left(\mathrm{r}_{\mathrm{p}}\right)$ values recorded in this study were similar to the range of positive values [0.49 for egg weight (EWT) vs egg length (ELH) to 0.89 for egg length $(\mathrm{ELH})$ vs egg width $(\mathrm{EWH})]$ reported by Ibom (2009). The positive correlation among most of the paired traits could imply that these traits were influenced by the same gene(s) in the same direction; hence selection and improvement in one trait could lead to improvement in the other. On the contrarily, the negative correlation values among some other pairs of traits could mean that these traits were influenced by different gene(s) in opposite direction and selection for improvement of one trait could lead to the reduction in performance of the other. These results agreed with the position of Ehiobu and Kyado (2000) that correlations between traits could be high or low, positive or negative. The authors also reported that positive correlations expressed among pairs of traits could suggest there is a direct relationship between them.

The percent egg shell colour distributions of the three mating models are presented in Figure 1. The results showed that the egg shell laid by the homozygous crosses (AMO X AMO and AMS X AMS) expressed two colours. The colours were mikado yellow and maize yellow for AMO XAMO model, while the colours expressed by the AMS X AMS model were mikado yellow and amber. The shell of eggs laid by the heterozygous cross (AMO X AMS) however expressed three colours, namely: mikado yellow, maize yellow and amber. This could imply that eggs laid by the heterozygous model were hybrids and contained the genes responsible for the egg shell colours of the homozygous crosses. The colours of egg shells were at variance with the yellow egg shell colour reported by Otu (2016) and the light yellow and milk white egg shell colours reported by Ibom et al. (2017) for the black skinned and white skinned ectotypes of A. marginata var. saturalis snails.

The differences in mean reproductive traits values and the colour of egg shells recorded in this study with earlier reports could be attributed to the variety/strain, age and sizes of snails used, genetic composition of the snails, differences in egg sizes among the mating models and other prevailing environmental conditions like temperature, relative humidity, type of feeding and soil conditions. The differences between egg traits correlation $\left(r_{p}\right)$ estimates of this study and those in available literature could be attributed among other things to differences in the pairs of traits, sizes of the eggs used, the genetic constitution of snails used and the prevailing environmental conditions. 


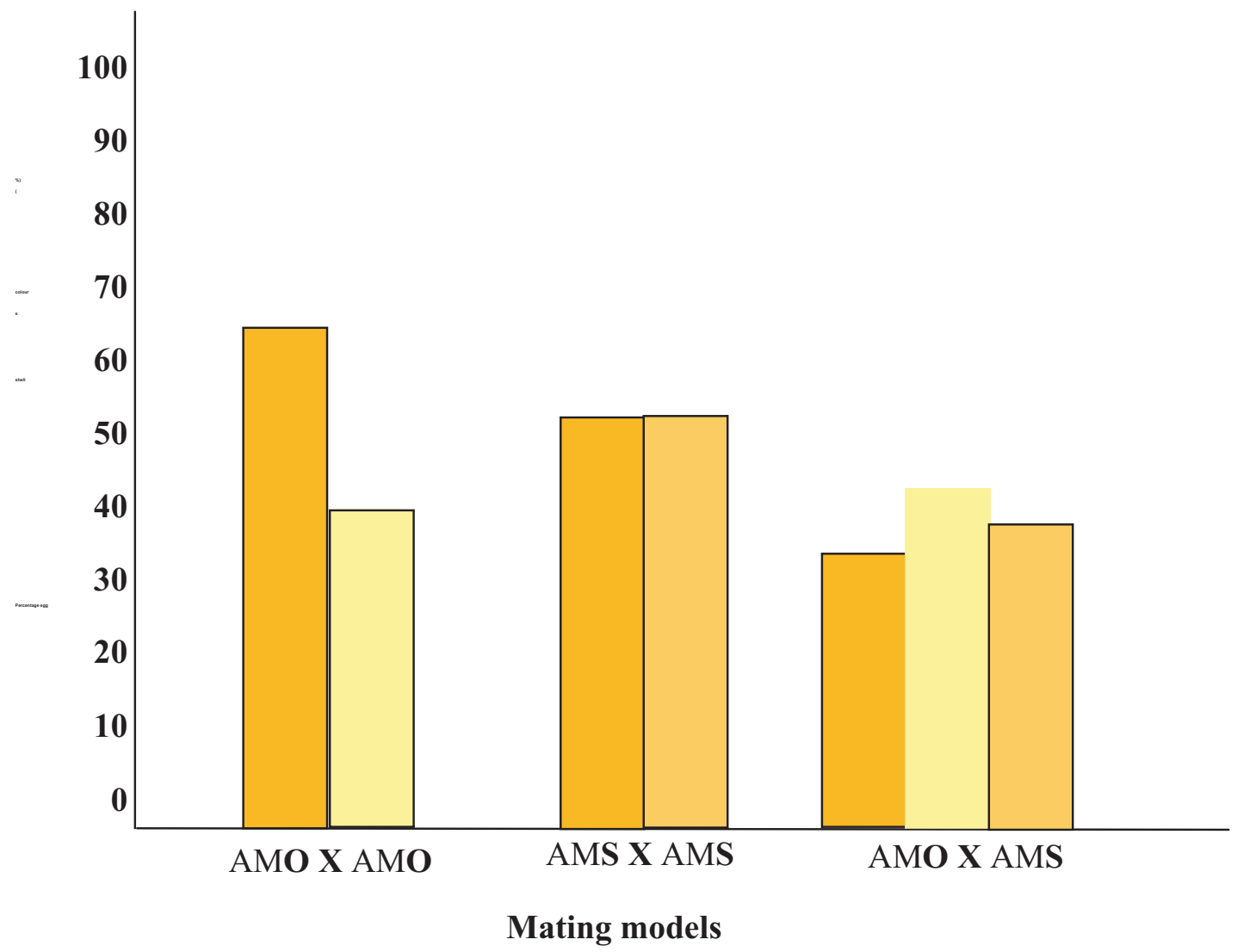

Fig. 1: Percentage egg shells colour distribution of $A$. marginata snails mating models.

KEY:

$$
\begin{aligned}
\square & =\text { Mikado yellow } \\
& =\text { Maize yellow } \\
\square & =\text { Amber }
\end{aligned}
$$

\section{Conclusion}

The relationship among the three mating models (AMO X AMO, AMS X AMS and AMO X AMS) evaluated revealed that the AMO X AMO and AMO X AMS models performed alike in some of the traits, while AMO X AMS (heterozygous cross) performed better than the two homozygous crosses (AMO X AMO and AMS X AMS) in some other traits, probably because of heterotic effect. The egg traits correlation estimates $\left(r_{p}\right)$ results also revealed that the AMO X AMS model recorded higher correlation coefficients for the pairs of traits evaluated. It could therefore be recommended that the AMO XAMS model be adopted by farmers for optimum production and returns on investment.

\section{References}

Ademosun, A. A. and Imevbore, E. A. 1988. An evaluation of the 
nutritive value of the African giant land snail, Archachatina marginata in relation to some popular protein sources. Journal of Animal Production Research. 8(2):76-87.

Akinnusi, O. 2004. Introduction to Snails and Snail Farming. $2^{\text {nd }}$ ed. Abeokuta, Nigeria. Triolas Exquisite Ventures. Pp. 90.

Akintomide, T. O. 2004. Tropical snail farming. $1^{\text {st }}$. Ed., Abeokuta, Nigeria. Oak Ventures. P. 56.

Amubode, F. O. 1994. Growth and Reproductive Performance of Two Species of African Giant Snail (Achatina achatina and Archachatina marginata). Journal of Tropical Forestry Research, 9\&10:68-74.

Amusan, J. A. and Omidiji, M. O. 1998. Edible land snails. A Technical guide to snail farming in the Tropics. Variety Printers Limited. $10-15$.

Duncan, D. B. 1955. Multiple ranges and multiple F-test. Biometrics 11:1 262.

Ehiobu, N. G. and Kyado, J. A. 2000. Heritability, Repeatability and Genetic correlation of Swine. Proceedings of the $25^{\text {th }}$ Annual Conference of Nigerian Society for Animal Production (NSAP). March 19 - 22, 2000. Umudike, Nigeria. Pp. $260-261$.

Falcanoer, D. S. 1989. Introduction to Quantitative Genetics. ${ }^{\text {rd }}$ ed. Burat Mill, England. Longman Group Limited. Pp. $162-169$.

Fapohunda, J. B., Omole, A. J., Obi, O. O. and Adebowale, E. A. 2007. Nutritional value of chicken offal as a replacement for local fish meal in growing snail. Proceedings of $32^{\text {nd }}$ Annual Conference of Nigerian Society for Animal Production (NSAP). March 18 - 21, 2007, University of Calabar, Calabar, Nigeria. Pp. $363-364$.

GenStat 2014. GenStat Release 10.3DE ( PC/Window Vista) VSN International Ltd. (Rothamsted Experimental Station). GenStat Discovery Edition 4.

Ibe, S. N. 1998. An Introduction to Genetics and Animal Breeding. Ikeja, Nigeria. Longman Nigeria. Plc. Pp. 150.

Ibom, L. A., Okon, B. and Essien, A. 2008. Morphometric analysis of eggs laid by two ectotypes of Snails Archachatina marginata (Swainson) raised in captivity. Global Journal of Agricultural Sciences. 7(2):119-121.

Ibom, L. A. 2009. Variations in reproductive and growth performance traits of Whiteskinned x Black-skinned African giant snail hatchling s [Archachatina marginata (Swainson)] in Obubra, Nigeria. Ph. D. Thesis, Department of Animal Science, University of Calabar, Calabar, Nigeria. Pp. 166.

Ibom L. A., Okon, B. and Adinya, I. B. 2011. Evaluation of growth and body traits of snailets obtained from the crossbreeding of black skinned $\mathrm{x}$ white skinned snails [Archachatina marginata (S)] in the Niger Delta area of Nigeria. African Journal of Agricultural Research.6(21):4968-4972.

Ibom, L. A., Okon, B., Adinya, I. B. and Okon, F. I. 2012. Reproductive Performance and correlation among Egg Traits of Two Ectotypes of Adult Snails 
(Archachatina marginata var.saturalis) in the Humid Tropics. World Journal of Zoology. 7(2):113-117.

Ibom, L. A., Okon, B., Okon, F. I. and Ow o y e m i , J. D . 2015 . Reproductive Performance of Archachatina marginata var. ovum Snails in Calabar, Nigeria. Journal of Molluscan Research. 1:64-73.

Ibom, L. A., Okon, B., Akpe, A. E. and Okon, F. I. 2017. Genetic and Phenotypic Variations in Egg Shell Colour of Two Ectotypes of Giant African Land Snail (Archachatina marginata var. saturalis). African Journal of Biotechnology. 16(31):1646-1649.

NMA 2016. Nigerian Metrological Agency, Margaret Ekpo International Airport, Calabar, Nigeria.

Odido, E. E. 2007. Evaluation of reproductive performance and some egg quality parameters of black $\mathrm{x}$ white (Albino snail) skinned snails (Archachatina marginata saturalis) in Cross River State. B. Agric. Project, Animal Science Department, University of Calabar, Calabar. Pp. 62.

Okon, B., Ibom, L. A., Williams, M. E. and Akpakpan, I. E. 2009. Comparative evaluation of reproductive performance and some egg quality parameters of black and white skinned snails. Global Journal of Agricultural Sciences. 8(1):77-80.

Okon, B., Ibom, L. A., Williams, M. E. and Akwa, N. T. 2010. Parity effects on Breeding and Morphometric Traits of Eggs and Hatchlings of Purebred Albino Snails [Archachatina marginata
(Swainson)]. Journal of Agriculture, Biotechnology and Ecology.3(1):44-54.

Okon, B. and Ibom, L.A. 2012. Snail breeding and snailery management. Freshdew productions, Calabar, Nigeria. Pp. 90.

Okon, B., Ibom, L. A., Williams, M. E. and Ekong, N. B. 2012a. Effects of Breeds on Reproductive Efficiency of Two Most Popular Snails [Archachatina marginata (S) and Achatina achatina (L)] in Nigeria. Journal of Agricultural Science, 4(8):236-245.

Okon, B., Ibom, L. A., Nsa, E. E. and Ubua, J. A. 2012b. Reproductive and Growth Traits of Parents and $\mathrm{F}_{1}$ Hatchlings of Achatina achatina (L) Snails under Mixed Feeding Regime with Graded Levels of $\mathrm{Swamp}$ Taro Cocoyam (Cytosperma chamissonis) and Pawpaw leaves (Carica papaya). Journal of Agricultural Science. 4(9):289-298.

Omole, A. J. 1997. The utilization of different energy supplements on performance characteristics of grower edible giant land snail (Archachatina marginata). M. Sc. Thesis. Department of Animal Science, University of Ibadan, Ibadan, Nigeria. Pp. $13-34$.

Omole, A. J., Osunkeye, O. J., Odejide, J. O., Sodamola, M. O. and Popoola, Y. A. 2011. The African Giant Land Snails. Green Choice Agric. Publications. Pp.56.

Otu, B. O. 2016. Genetic and Phenotypic Parameters of Growth and Reproduction among $\mathrm{F}_{1}$ and $\mathrm{F}_{2}$ Crossbreds of Two Ectotypes of Archachatina marginata (S) 
Snails. Ph. D. Thesis. Department of Animal Science, University of Calabar, Calabar, Nigeria. Pp. 241.

Raggett, D. 2002. Dave Raggett's Introduction to CSS. World Wide Consortium. Retrieved June, 2017.

Ubua, J. A. 2004. Reproductive Potentials of two snails - Archachatina marginata ovum and Archachatina marginata saturalis in the Swamp Forest Zone of Nigeria. M. Sc. Thesis, Department of Animal Science, University of Calabar, Calabar, Nigeria. Pp. 85.
Wosu, L. O. 2003. Commercial Snailery Production, A Guide. AP Express Publishers Limited, Nsukka, Nigeria. Pp. 5-35.

Received: $15^{\text {th }}$ October, 2017

Accepted: $20^{\text {th }}$ February, 2018 